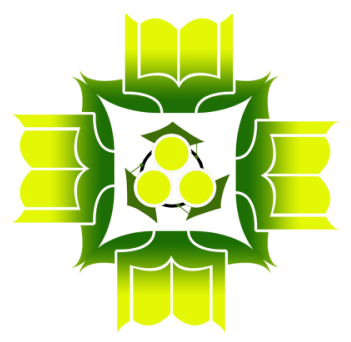

\title{
ANALYSIS OF E-LEARNING SYSTEMS SUCCESS USING GOOGLE CLASSROOM IN PGMI MAJOR OF UNIVERSITAS ISLAM LAMONGAN: SEM (STRUCTURAL EQUATION MODELLING)
}

\author{
Silviana Nur Faizah \\ Universitas Islam Lamongan \\ silviana_nurfaizah@unisla.ac.id \\ Ummu Khairiyah \\ Universitas Islam Lamongan \\ ummukhairiyah@unisla.ac.id \\ Uswatun Anisah \\ Universitas Islam Lamongan \\ uswatunanisah86@gmail.com
}

\begin{abstract}
Online learning is a learning approach during the COVID-19 pandemic, Google Classroom is an e-learning platform used by the Islamic University of Lamongan (Unisla) Madrasah Ibtidaiyah Teacher Education study program (PGMI). This study aims to analyze the factors that influence the success of online learning with google classroom during the covid 19 pandemic. The research data was collected through a google form-assisted questionnaire with a sample of 127 PGMI Unisla students. The data analysis used is Structural Equation Modeling (SEM) assisted by Smart PLS. The results of the study indicate that system quality, quality of instructors, perceived usefulness, and student satisfaction are factors that influence the success of online learning with Google Classroom. These findings can be used as input in determining the improvement strategy (planning and improvement) of using google classroom for the Success of online learning in the future.
\end{abstract}

Keywords: Online Learning, Google classroom, Covid-19 pandemic, PLSSEM approach, Success of online learning. 


\begin{abstract}
Abstrak
Pembelajaran daring menjadi pendekatan pembelajaran di masa pandemi covid 19, Google classroom merupakan platform e-learning yang digunakan program studi Pendidikan Guru Madrasah Ibtidaiyah (PGMI) Universitas Islam Lamongan (Unisla). Penelitian ini bertujuan untuk menganalisis faktor-faktor yang mempengaruhi keberhasilan pembelajaran daring dengan google classroom selama pandemi covid 19. Data penelitian dikumpulkan melalui kuisioner berbantuan google form dengan jumlah sampel 127 mahasiswa PGMI Unisla. Analisis data yang digunakan yaitu Structural Equation Modelling (SEM) berbantuan Smart PLS. Hasil penelitian menunjukkan bahwa system quality, quality of instructors, perceived usefulness, and student satisfaction merupakan faktor yang mempengaruhi keberhasilan pembelajaran daring dengan google classroom. Temuan ini dapat dijadikan masukan dalam menentukan strategi perbaikan (perencanaan dan perbaikan) penggunaan google classroom untuk keberhasilan pembelajaran daring di masa mendatang.
\end{abstract}

Kata Kunci: Pembelajaran Daring, Google Classroom, Pandemi Covid-19, Pendekatan PLS-SEM, Keberhasilan Pembelajaran Daring.

\title{
INTRODUCTION
}

Presidential Decree number 11 of 2020 mentions the Determination of the COVID-19 public health emergency in Indonesia, which must be carried out following the provisions of laws and regulations, the Directorate General of Higher Education carried out various strategies to carry out these efforts. In avoiding transmission and spreading the COVID-19 Pandemic, policies have been issued to work, worship, and study from home, face-to-face learning has been changed to online learning. The implementation of online learning makes all parties help and support each other. The spirit of collaboration, cooperation, and nationality expecting to make the learning process more meaningful. Refers to the Joint Decree of the Four Ministers Number 01/KB/2020 dated June 15, 2020, regarding Guidelines for the Implementation of Learning in the 2020/2021 Academic Year and the 2020/2021 Academic Year in the Corona Virus Disease (Covid-19) Pandemic Period that the learning method in higher education in all zones must be carried out online for theoretical courses and wherever possible also for the practical course (Direktorat Jenderal Pendidikan Tinggi Kemdikbud RI, 2020). 
Following up on this to break the chain of the spread of the Covid-19 virus, the Governor of East Java in Governor Decree No. 34 of 2021 which states that learning activities are carried out online. Referring to the Governor's Decree No. 34 in 2021 lectures at the PGMI study program at the Islamic University of Lamongan are carried out online (e-learning) in all subjects.

E-learning is either a medium for transferring knowledge but also a method of transferring information from one person to another. E-learning is a solution to the impossibility of implementing face-to-face learning, according to Behnam, there are several advantages to the implementation of e-learning during the pandemic including 1) bridging the limitations of time and place, 2) providing equal opportunities for students to carry out lectures in every condition,3) Enhance group collaboration: Learners and teachers can be linked together through chat, voice, and video conferencing, interactive TV, virtual classrooms and eliminating physical separation simultaneously. Through this, students are active in the learning process and are interactive, 4) Can access directly many other lecture sources, 5) Expand the dimensions of obtaining information to the international level, 6) can determine the level of development of lectures (Talebian et al., 2014).

After the COVID-19 crisis, online education has become a pedagogical shift from traditional methods to modern learning approaches from classrooms to Zoom, from personal to virtual, and from seminars to webinars. Previously, e-learning, distance education, and correspondence courses were popular as part of non-formal education, but until now, it seems that it will gradually replace the formal education system if the situation continues over time. Some of the most popular online communication platforms that will change the purpose and direction of the entire education system worldwide in the post-COVID-19 state are Start.me, Neo, Classtime, Classwize, Ted-Ed, Coursera, Google Classroom, Bakpax, Pronto, Skillshare, ClassDojo, Edmodo, Blackboard Learn, Parlay, Docebo, Feedback Fruits, Udemy, WeVideo, WizIQ, Flipgrid, Codeacademy, Gynzy, Adobe Captivate, Seesaw, Edx, GoGuardian, Elucidat, Us, Pluralsight, G Suite, Otus, Articulate 360, Floop, Future Learn, Hapara, Shift, Lectora Inspire, Kialo Edu, Buncee, LanSchool, and many more (Mishra et al., 2020).

Based on the results of a survey conducted in 2020 by the Indonesian Survey Flow Institute (ASI), Google classroom is the most frequently used platform for 
distance learning as many as $26.1 \%$ of people in 34 provinces in Indonesia (Kamil, 2020). The PGMI study program also participates in using google classroom as an online communication platform during online learning. Google Classroom was chosen as an online learning platform because of several advantages, namely being free to use, facilitating teachers in making and managing assignments, providing feedback efficiently, and enabling interactive communication, integrated with various applications including Youtube, Google Doc, Google Slides, Google Drive, Google Form, and others (Harefa \& Sumiyati, 2020; R. Ramadhani et al., 2019; Shaharanee et al., 2016).

Many studies related to the Success factors of e-learning have been carried out. As in Ouajdouni et al., 2021, this study evaluates the Success factors of using e-learning with various platforms used in universities in Morocco. The results of the study stated that 1) System quality; (2) Instructor quality; (3) Social influence; (4) Learner Computer Anxiety; (5) Perceive Usefulness; (6) E-Learning System Use; (7) E-Learning satisfaction; (8) The Success of the e-learning system is a model that has a high degree of suitability and completeness to Evaluate the Success of e-learning (Ouajdouni et al., 2021).

The effectiveness of using google classroom e-learning is also a research topic of Shaharanee et al. (2016), this study measures the effectiveness of learning with google classroom with the TAM model developed by Davis with two determinants of the effectiveness of e-learning, namely: perception of ease of use and perceived usefulness. The result is that students are satisfied with Google Classroom so that it shows it is effective as an active learning tool.

Analysis of the Successful implementation of E-Learning was also investigated by Seliana et al. (2020), this study measures the Success of using google classroom using the Delone and McLean Success model. The results showed that the analysis of the Success of using e-learning at the Faculty of Engineering, Riau University at all levels of Success was good. Success at the semantic level is the highest Success, then Success at the level of effectiveness, and Success at the technical level.

As was done by Rahmat et al. (2019) in evaluating the success of E-Learning in the Delone and McLean Information System Perspective, the results of research 
on information quality, system quality, and service quality have a positive effect on E-Learner Satisfaction. Service quality and information quality have a positive effect on usage. Use has a positive effect on E-Learner Satisfaction, and use and E-Learner Satisfaction has a positive effect on net results.

When compared with several previous studies, this study analyzes the success factors of learning through google classroom with the model developed by Ouajdouni et al. (2021) is an element of novelty that previous researchers, especially in Indonesia, have studied the DeLone and McLean models more to analyze the success of e-learning. In addition, it focuses on the use of the Google classroom platform by using the e-learning success model developed by Ouajdouni et al. (2021) during the covid-19 pandemic, this study is a novelty.

This study aims to determine the factors influencing the success of online learning google classroom - based on the Madrasah Ibtidaiyah teacher education program at the Islamic University of Lamongan by using the Ouajdouni et al. (2021). ). Identification of factors influencing the success of online learning Google Classroom-based will be needed to determine improvement strategies (planning and improvement) for the use of Google Classroom for the success of online learning in the future.

\section{METHODS}

This research was conducted at the Madrasah Ibtidaiyah Teacher Education study program, Lamongan Islamic University. The data collection technique in this study was using a google form-assisted questionnaire which was filled out directly by respondents who were students of the Ibtidaiyah Madrasah Teacher Education Study Program class 2018, 2019, and 2020. The questionnaire consisted of 36 questions. The questionnaire in this study used a Likert scale with a weighted score of (a) Strongly Agree with a score of 5, (b) Agree with a score of 4 , (c) Doubtful with a score of 3, (d) Disagree) with a score of 2, and (e ) Strongly Disagree with a score of 1 .

Partial Least Squares (PLS-SEM) analysis was used to analyze descriptively the conditions of online learning through google classroom at PGMI Unisla as the right method to analyze the hypothesis and model of this research. 
Data analysis was carried out in three stages. The first stage is to analyze the measurement model or outer model to determine the validity and reliability of each indicator on the variable. Furthermore, in the second stage, an analysis of the structural model or inner model is carried out to determine the significance of the research hypothesis, and the third stage is hypothesis testing (Furadantin, 2018; Wong, 2013).

Eight variable studies were adapted from (Ouajdouni et al., 2021) including: (1) System quality; (2) Instructor quality (3) Social influence; (4) Learner Computer Anxiety; (5) Perceive Usefulness; (6) E-Learning System Use; (7) E-Learning satisfaction e-learning; (8) The Success of the e-learning system. The structural model in this study can be seen in Figure 1.

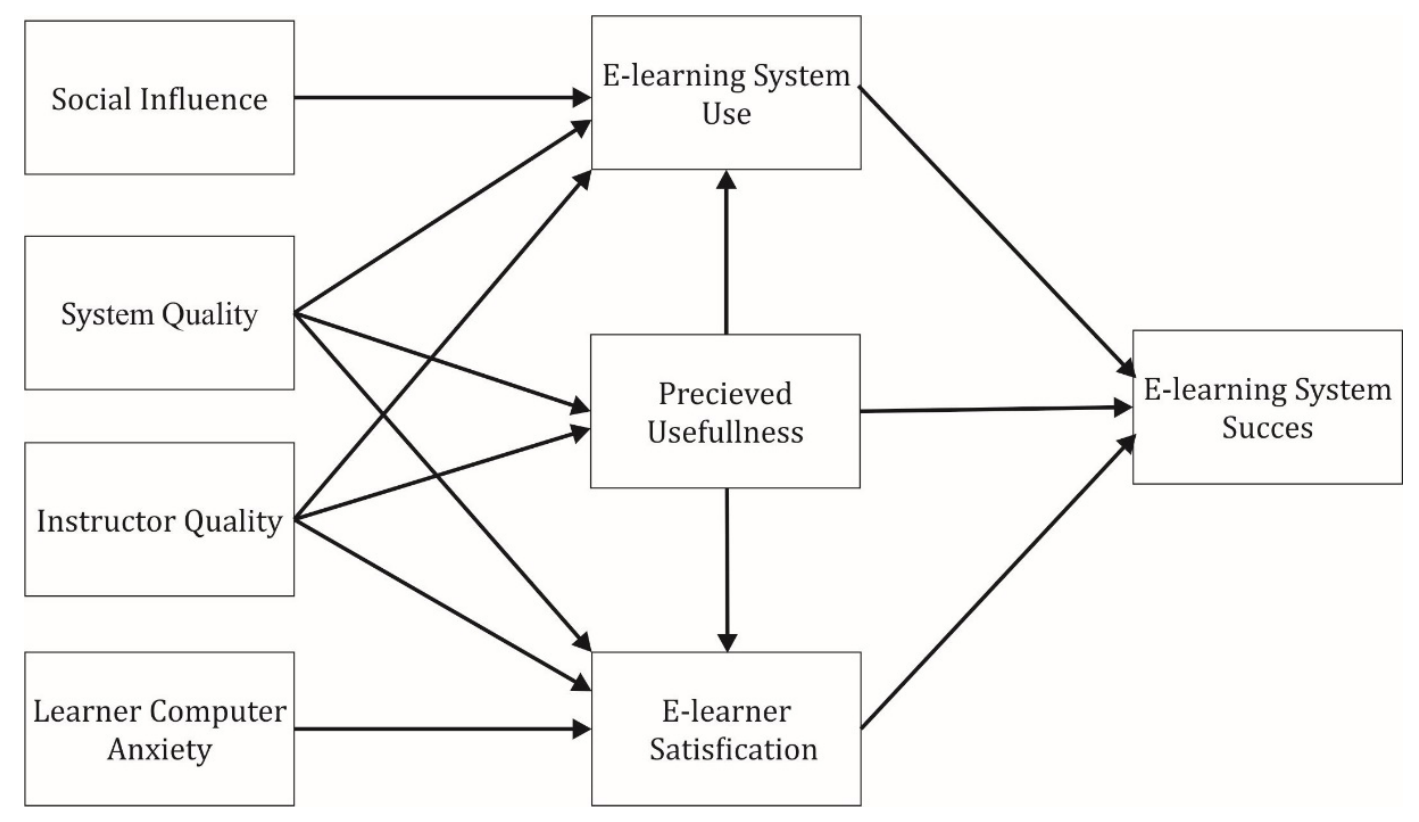

Gambar 1. Structural Model of Research

\section{RESULTS AND DISCUSSION}

The success of online learning through google classroom at PGMI Unisla is measured by referring to the E-Learning System Success Ouajdouni et al., 2021. The questionnaire has been filled out by 127 students and analyzed in two stages, namely the analysis of the measurement model or the outer model and the 
evaluation of the structural model or the inner model. The first stage is to analyze the measurement model or the outer model. This structural model analysis aims to determine how valid and reliable the indicators reflect the construct variables (Furadantin, 2018; Rahmat et al., 2019). Analysis of the measurement model can be seen from the four main parameters, namely indicator reliability, internal consistency reliability, convergent validity, and discriminant validity. The second stage is to analyze the structural model or inner model to determine the significance of the research hypothesis (Wong, 2013).

\section{Measurement Analysis Model or Outer model}

Analysis of the measurement model or outer model. This structural model analysis aims to determine how valid and reliable the indicators reflect the construct variables (Furadantin, 2018; Hair et al., 2014; Rahmat et al., 2019). Analysis of the measurement model can be seen from the four main parameters, namely indicator reliability, internal consistency reliability, convergent validity, and discriminant validity.

Indicator reliability aims to determine whether the indicator of the measurement of the latent variable is reliable or not, with reliable criteria if the reliability indicator value is $>0.7$. Table 1 shows that the value of the reliability indicator is $>0.7$, so it can be concluded that all indicators of the measurement of the latent variable are declared reliable.

Internal consistency reliability is used to assess whether the latent variable has internal consistency reliability or not, by looking at the composite reliability value (Hair et al., 2014). With reliable criteria if the composite value $>0.7$, the composite value $>0.7$. Based on the composite values in table 1 , it is concluded that the latent variable has good reliability (Furadantin, 2018; Sarstedt et al., 2017). 
Table 1. Convergent Validity

\begin{tabular}{|c|c|c|c|c|c|}
\hline Variables & Indikator & Loadings & $\begin{array}{c}\text { Indicator } \\
\text { Reliability } \\
\text { (i.e., } \\
\text { loadings) }\end{array}$ & $\begin{array}{l}\text { Composite } \\
\text { Reliability }\end{array}$ & AVE \\
\hline \multirow{4}{*}{ Social Influence } & SI 1 & 0.840 & 0.840 & \multirow{4}{*}{0.897} & \multirow{4}{*}{0.686} \\
\hline & SI 2 & 0.856 & 0.856 & & \\
\hline & SI 3 & 0.811 & 0.811 & & \\
\hline & SI 4 & 0.804 & 0.804 & & \\
\hline \multirow[t]{3}{*}{ System Quality } & SQ1 & 0.859 & 0.859 & \multirow{3}{*}{0.862} & \multirow{3}{*}{0.676} \\
\hline & SQ 2 & 0.827 & 0.827 & & \\
\hline & SQ 3 & 0.779 & 0.779 & & \\
\hline \multirow{5}{*}{ Instructor Quality } & IQ 1 & 0.722 & 0.722 & \multirow{5}{*}{0.871} & \multirow{5}{*}{0.574} \\
\hline & IQ 2 & 0.746 & 0.746 & & \\
\hline & IQ 3 & 0.720 & 0.720 & & \\
\hline & IQ 4 & 0.764 & 0.764 & & \\
\hline & IQ 5 & 0.832 & 0.832 & & \\
\hline \multirow{3}{*}{$\begin{array}{l}\text { Learner Computer } \\
\text { Anxiety (LCA) }\end{array}$} & LCA 1 & 0.901 & 0.901 & \multirow{3}{*}{0.938} & \multirow{3}{*}{0.834} \\
\hline & LCA 2 & 0.942 & 0.942 & & \\
\hline & LCA 3 & 0.897 & 0.897 & & \\
\hline \multirow{4}{*}{ E-Learning System Use } & ELU 1 & 0.857 & 0.814 & \multirow{4}{*}{0.937} & \multirow{4}{*}{0.713} \\
\hline & ELU 2 & 0.828 & 0.884 & & \\
\hline & ELU 3 & 0.825 & 0.800 & & \\
\hline & ELU 4 & 0.866 & 0.867 & & \\
\hline \multirow{4}{*}{$\begin{array}{l}\text { Perceived Usefulness } \\
\text { (PU) }\end{array}$} & PU 1 & 0.821 & 0.864 & \multirow{4}{*}{0.908} & \multirow{4}{*}{0.739} \\
\hline & PU 2 & 0.874 & 0.829 & & \\
\hline & PU 3 & 0.870 & 0.857 & & \\
\hline & PU 4 & 0.873 & 0.828 & & \\
\hline \multirow{6}{*}{ E-Learner Satisfaction } & ELS 1 & 0.868 & 0.825 & \multirow{6}{*}{0.919} & \multirow{6}{*}{0.737} \\
\hline & ELS 2 & 0.799 & 0.866 & & \\
\hline & ELS 3 & 0.840 & 0.821 & & \\
\hline & ELS 4 & 0.860 & 0.874 & & \\
\hline & ELS 5 & 0.885 & 0.870 & & \\
\hline & ELS 6 & 0.895 & 0.873 & & \\
\hline \multirow{6}{*}{$\begin{array}{l}\text { E-Learning System Success } \\
\text { (ELSS) }\end{array}$} & ELSS 1 & 0.814 & 0.868 & \multirow{6}{*}{0.944} & \multirow{6}{*}{0.712} \\
\hline & ELSS 2 & 0.884 & 0.799 & & \\
\hline & ELSS 3 & 0.800 & 0.840 & & \\
\hline & ELSS 4 & 0.867 & 0.860 & & \\
\hline & ELSS 5 & 0.864 & 0.885 & & \\
\hline & ELSS 6 & 0.829 & 0.895 & & \\
\hline
\end{tabular}


Convergent validity (AVE) in table 1 found that all AVE values were 0.5 can be concluded that the latent variable was declared valid (Wong, 2013). Discriminant validity aims to assess whether an indicator has reflected its latent variables well, with the principle that each indicator must be highly correlated with latent variables. Discriminant validity was determined from the crossloadings value and the Fornell lacker criterion value. It is known that in table 2 the value of cross-loadings has met the requirements, where each indicator on the latent variable is higher than the value of cross-loading on the other latent variables (Hair et al., 2014).

Table 2. Discriminant Validity- Loading and Cross-Loading Criterion

\begin{tabular}{ccccccccc}
\hline & SI & SQ & IQ & LCA & ELSS & ELU & PU & ELS \\
\hline SI 1 & 0.840 & 0.498 & 0.582 & 0.277 & 0.575 & 0.445 & 0.446 & 0.529 \\
\hline SI 2 & 0.856 & 0.417 & 0.475 & 0.271 & 0.483 & 0.346 & 0.330 & 0.376 \\
\hline SI 3 & 0.811 & 0.429 & 0.433 & 0.204 & 0.478 & 0.279 & 0.337 & 0.440 \\
\hline SI 4 & 0.804 & 0.452 & 0.564 & 0.158 & 0.463 & 0.507 & 0.408 & 0.336 \\
\hline SQ 1 & 0.525 & 0.859 & 0.587 & 0.357 & 0.499 & 0.455 & 0.347 & 0.473 \\
\hline SQ 2 & 0.423 & 0.827 & 0.464 & 0.316 & 0.514 & 0.376 & 0.397 & 0.512 \\
\hline SQ 3 & 0.402 & 0.779 & 0.500 & 0.259 & 0.400 & 0.453 & 0.398 & 0.326 \\
\hline IQ 1 & 0.485 & 0.436 & 0.722 & 0.195 & 0.504 & 0.464 & 0.448 & 0.432 \\
\hline IQ 2 & 0.491 & 0.487 & 0.746 & 0.309 & 0.535 & 0.320 & 0.390 & 0.473 \\
\hline IQ 3 & 0.428 & 0.474 & 0.720 & 0.267 & 0.516 & 0.312 & 0.290 & 0.440 \\
\hline IQ 4 & 0.493 & 0.479 & 0.764 & 0.124 & 0.489 & 0.448 & 0.387 & 0.339 \\
\hline IQ 5 & 0.508 & 0.509 & 0.832 & 0.246 & 0.611 & 0.494 & 0.445 & 0.469 \\
\hline LCA 1 & 0.199 & 0.336 & 0.281 & 0.901 & 0.387 & 0.344 & 0.337 & 0.348 \\
\hline LCA 2 & 0.194 & 0.330 & 0.230 & 0.942 & 0.310 & 0.315 & 0.296 & 0.279 \\
\hline LCA 3 & 0.344 & 0.370 & 0.301 & 0.897 & 0.361 & 0.344 & 0.283 & 0.327 \\
\hline ELU 1 & 0.394 & 0.421 & 0.455 & 0.318 & 0.486 & 0.857 & 0.657 & 0.430 \\
\hline ELU 2 & 0.475 & 0.498 & 0.498 & 0.385 & 0.665 & 0.828 & 0.700 & 0.635 \\
\hline ELU 3 & 0.344 & 0.406 & 0.417 & 0.207 & 0.467 & 0.825 & 0.627 & 0.529 \\
\hline ELU 4 & 0.459 & 0.418 & 0.463 & 0.313 & 0.574 & 0.866 & 0.708 & 0.450 \\
\hline PU 1 & 0.404 & 0.372 & 0.406 & 0.238 & 0.559 & 0.677 & 0.821 & 0.532 \\
\hline PU 2 & 0.407 & 0.425 & 0.482 & 0.216 & 0.619 & 0.670 & 0.874 & 0.613 \\
\hline PU 3 & 0.375 & 0.375 & 0.441 & 0.326 & 0.565 & 0.669 & 0.870 & 0.559 \\
\hline PU 4 & 0.431 & 0.412 & 0.469 & 0.376 & 0.589 & 0.736 & 0.873 & 0.522 \\
\hline ELS 1 & 0.506 & 0.499 & 0.482 & 0.245 & 0.717 & 0.577 & 0.596 & 0.868 \\
\hline & & & & & & & &
\end{tabular}


Silviana Nur Faizah, Ummu Khairiyah, and Uswatun Anisah

\begin{tabular}{ccccccccc}
\hline & SI & SQ & IQ & LCA & ELSS & ELU & PU & ELS \\
\hline ELS 2 & 0.425 & 0.423 & 0.437 & 0.287 & 0.646 & 0.481 & 0.573 & 0.799 \\
\hline ELS 3 & 0.357 & 0.428 & 0.393 & 0.308 & 0.682 & 0.518 & 0.508 & 0.840 \\
\hline ELS 4 & 0.344 & 0.344 & 0.423 & 0.204 & 0.682 & 0.476 & 0.479 & 0.860 \\
\hline ELS 5 & 0.469 & 0.548 & 0.546 & 0.366 & 0.790 & 0.526 & 0.570 & 0.885 \\
\hline ELS 6 & 0.479 & 0.488 & 0.612 & 0.379 & 0.842 & 0.553 & 0.599 & 0.895 \\
\hline ELSS1 & 0.437 & 0.455 & 0.501 & 0.295 & 0.814 & 0.562 & 0.547 & 0.726 \\
\hline ELSS2 & 0.538 & 0.463 & 0.607 & 0.273 & 0.884 & 0.597 & 0.615 & 0.731 \\
\hline ELSS3 & 0.544 & 0.458 & 0.530 & 0.322 & 0.800 & 0.459 & 0.540 & 0.672 \\
\hline ELSS4 & 0.552 & 0.537 & 0.676 & 0.417 & 0.867 & 0.602 & 0.613 & 0.732 \\
\hline ELSS5 & 0.494 & 0.505 & 0.580 & 0.386 & 0.864 & 0.533 & 0.547 & 0.716 \\
\hline ELSS6 & 0.506 & 0.490 & 0.655 & 0.282 & 0.829 & 0.563 & 0.569 & 0.734 \\
\hline
\end{tabular}

Furthermore, discriminant validity is tested with the Fornell lacker criterion value in table 3 which shows that each indicator is highly correlated with the latent variable, for example, the Fornell lacker criterion value on the latent variable is 0.822 . the value $(0.822)$ is greater than the correlation value in the "SQ" column $(0.629,0.379,0.575,0.519,0.462$ and 0.535$)$ and the value $(0.822)$ is greater than the value in the "SQ" row (0.548) (Wong, 2013).

Table 3. Discriminant validity (Fornell Lacker Criterion)

\begin{tabular}{lcccccccc}
\hline \multicolumn{1}{c}{ Variable } & SI & SQ & IQ & LCA & ELU & PU & ELS & ELSS \\
\hline Social Influence (SI) & 0.828 & & & & & & & \\
\hline System Quality (SQ) & 0.548 & 0.822 & & & & & & \\
\hline Instructor Quality (IQ) & 0.636 & 0.629 & 0.758 & & & & & \\
\hline $\begin{array}{l}\text { Learner Computer } \\
\text { Anxiety (LCA) }\end{array}$ & 0.271 & 0.379 & 0.299 & 0.913 & & & & \\
\hline $\begin{array}{l}\text { E-Learning System Use } \\
\text { (ELU)) }\end{array}$ & 0.606 & 0.575 & 0.703 & 0.390 & 0.844 & & 0.844 \\
\hline $\begin{array}{l}\text { Perceived Usefulness } \\
\text { (PU) }\end{array}$ & 0.501 & 0.519 & 0.546 & 0.368 & 0.800 & 0.860 & 0.657 \\
\hline $\begin{array}{l}\text { E-Learner Satisfaction } \\
\text { (ELS) }\end{array}$ & 0.470 & 0.462 & 0.524 & 0.336 & 0.609 & 0.648 & 0.858 & 0.679 \\
\hline $\begin{array}{l}\text { E-Learning System } \\
\text { Success (ELSS) }\end{array}$ & 0.505 & 0.535 & 0.569 & 0.352 & 0.844 & & 0.852 \\
\hline
\end{tabular}




\section{Structural Model Analysis or Inner Model}

According to Sarstedt et al. In analyzing the structural model or the inner model, researchers need to ensure that there is no collinearity between latent variables and the predictive ability of the model. The results of the collinearity analysis in this study indicate that there is no collinearity between variables because it has met the criteria for Variance Inflation Factor (VIF) $<5$ and tolerance values > 0.2 (see Figure 2) (Wong, 2013).

\begin{tabular}{|c|c|c|c|c|c|c|c|c|}
\hline \multicolumn{9}{|c|}{ Coefficients $^{\mathrm{a}}$} \\
\hline \multirow[b]{2}{*}{ Model } & & \multicolumn{2}{|c|}{$\begin{array}{l}\text { Unstandardized } \\
\text { Coefficients }\end{array}$} & \multirow{2}{*}{\begin{tabular}{|c}
$\begin{array}{c}\text { Standardized } \\
\text { Coefficients }\end{array}$ \\
Beta \\
\end{tabular}} & \multirow[b]{2}{*}{$\mathrm{t}$} & \multirow[b]{2}{*}{ Sig. } & \multicolumn{2}{|c|}{$\begin{array}{l}\text { Collinearity } \\
\text { Statistics }\end{array}$} \\
\hline & & $\mathrm{B}$ & Std. Error & & & & Tolerance & VIF \\
\hline 1 & (Constant) & 0.143 & 1.229 & & 0.117 & 0.907 & & \\
\hline & Social Influence (SI) & 0.129 & 0.077 & 0.089 & 1.685 & 0.095 & 0.577 & 1.734 \\
\hline & System Quality (SQ) & -0.028 & 0.102 & -0.015 & -0.274 & 0.785 & 0.506 & 1.977 \\
\hline & Instructor Quality (IQ) & 0.348 & 0.080 & 0.257 & 4.346 & 0.000 & 0.464 & 2.153 \\
\hline & $\begin{array}{l}\text { Learner Computer } \\
\text { Anxiety (LCA) }\end{array}$ & 0.070 & 0.053 & 0.058 & 1.307 & 0.194 & 0.813 & 1.230 \\
\hline & $\begin{array}{l}\text { E-Learning System Use } \\
(\text { ELU)) }\end{array}$ & 0.045 & 0.090 & 0.035 & 0.493 & 0.623 & 0.326 & 3.069 \\
\hline & Perceived Usefullness & 0.143 & 0.094 & 0.108 & 1.520 & 0.131 & 0.321 & 3.115 \\
\hline & E-Learner Satisfication & 0.480 & 0.051 & 0.552 & 9.410 & 0.000 & 0.471 & 2.122 \\
\hline
\end{tabular}

Figure 2. Tolerance and VIF values in SPSS Output

Furthermore, an analysis of the coefficient of determination $\left(\mathrm{R}^{2}\right)$ was carried out which aims to determine the combination of exogenous variables that together affect the value of endogenous variables. The expected $R^{2}$ value is between 0 and 1 , with the criteria for $\mathrm{R}^{2} 0,75,0,50$, dan 0,25 menunjukkan bahwa model kuat, moderat, dan lemah (Hair et al., 2014). As shown in Figure 3, the coefficient of determination of E-Learner Satisfaction shows a weak model. $\mathrm{R}^{2}$ perceived usefulness and E-Learning System Success showed a moderate model, namely 0.677 and 0.504, respectively. Furthermore, $R^{2}$ E-Learning System Use shows a strong model of 0.755 .

Figure 3 shows the value of Cross-validated Redundancy $\left(Q^{2}\right)$ is greater than zero, in conclusion, the model has accurate predictive relevance. Further analysis (see Figure 3) Perceive usefulness variable has moderate predictive relevance and E-Learning System Use, E-Learner Satisfaction-learning and E-Learning System 
Success variables have high predictive relevance. This refers to Sarstedt's opinion which states that the relative size of the predictive relevance of exogenous for endogenous variables with $Q^{2}$ values of 0.02 (small), 0.15 (moderate), and 0.35 (strong) (Sarstedt et al., 2017).

The Effect size value $\left(\mathrm{f}^{2}\right)$ in table 4 shows that there is a strong effect between E-Learner Satisfaction on E-Learning System Success. The criterion is that there is no influence between social influence and instructor quality on E-Learning System Use; the concerns of learners using computers on e-learning satisfaction; perceived usefulness to E-Learning System Success, and other than that it has little effect. According to Cohen, the criteria for each Effect Size $\left(\mathrm{f}^{2}\right)$ are 0.02 (small), 0.15 (medium), and 0.35 (strong), while the value of Effect Size $\left(\mathrm{f}^{2}\right)<0.02$ is declared to have no effect (Sarstedt et al., 2017).

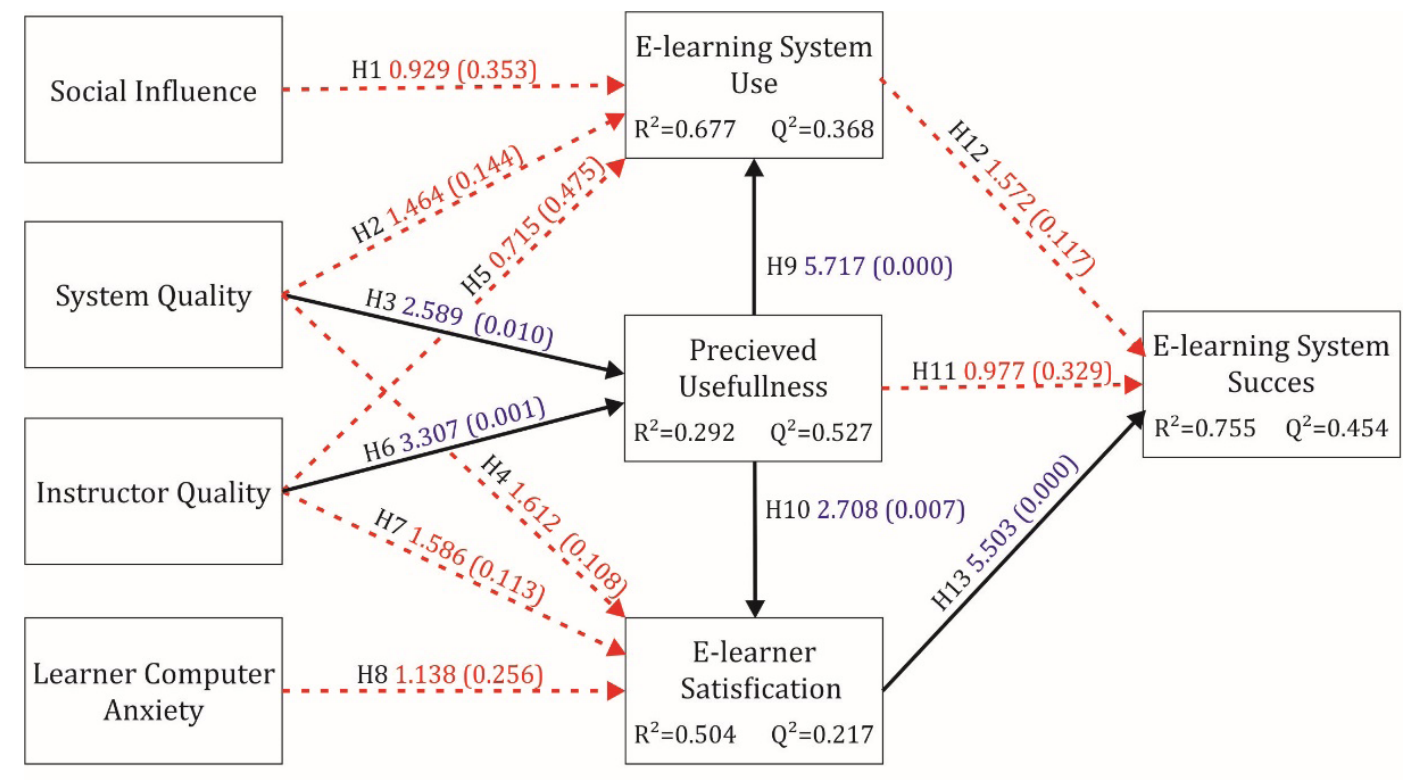

Path Coefficient \& t-value

T-value $=1.96$ - Sig. at $\mathrm{p}$-value $<0.05$

Figure 3. Structural Equation Model Analysis 
Analysis of E-learning Systems Success Using Google Classroom in PGMI Major of ......

Tabel 4. Effect Size $\left(\mathrm{f}^{2}\right)$

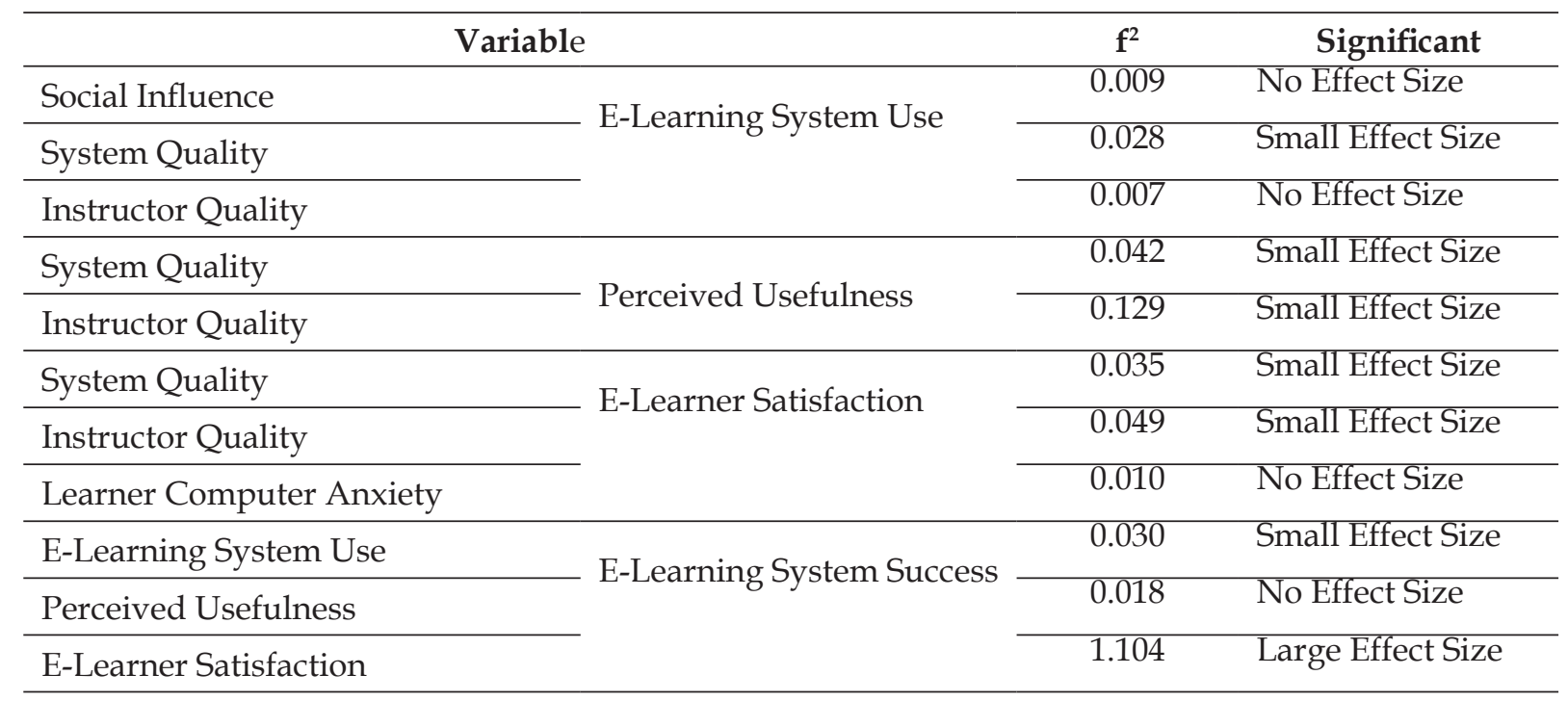

The hypothesis test in this study used a significant level of 5\% with a t-table value of 1.96. The test criteria $\mathrm{H}_{0}$ is accepted if the t-statistic value is $<1.96$, and $\mathrm{H}_{\mathrm{a}}$ is accepted if the $\mathrm{t}$-statistic value is $>1.96$. The findings show that the effect of social influence on E-Learning System Use is not significant $(0.929<1.96)$, the effect of system quality e-learning on E-Learning System Use is not significant $(1,464<1.96)$, the effect of system quality e-learning on perceived usefulness is significant. $(2,589>1.96)$, the effect of e-learning system quality on E-Learner Satisfaction is not significant $(1,612<1.96)$, the influence of instructor quality on E-Learner Satisfaction-learning is not significant $(1,586<1.96)$, the influence of instructor quality on perceived usefulness is significant (3.307>1.96). As mentioned H1, H2, H4, H5 were not significant while $\mathrm{H} 3$ and $\mathrm{H} 6$ were significant.

The influence of instructor quality on E-Learning System Use is not significant $(0.715<1.96)$, the effect of user/learners' concerns who use computers on E-Learner Satisfaction-learning is not significant $(1.138<1.96)$, the effect of perceived usefulness on E-Learning System Use is significant (5.717>1.96), the effect of perceived usefulness on E-Learner Satisfaction-learning is significant (2.708>1.96), the effect of perceived usefulness on E-Learning System Success is not significant $(0.977<1.96)$, the effect of E-Learning System Use on E-Learning -Learning System Success $(1.572<1.96)$, the effect of E-Learner Satisfaction-learning on E-Learning System Success is significant (5.503>1.96). Therefore H7, H8, H11, and H12 are not 
significant while $\mathrm{H} 9, \mathrm{H} 10$, and $\mathrm{H} 13$ are significant as illustrated in Table 5 and the results of the structural model are as shown in Figure 3.

Table 5. Result of Path Analysis and Hypothesis Testing

\begin{tabular}{|c|c|c|c|c|}
\hline & Hipotesis Hubungan & $\begin{array}{c}\mathrm{T}- \\
\text { Statistics }\end{array}$ & $\begin{array}{c}\mathrm{P} \\
\text { Values }\end{array}$ & Support \\
\hline $\mathrm{H} 1$ & : Social Influence -> E-Learning System Use & 0.929 & 0.353 & Rejected \\
\hline $\mathrm{H} 2$ & : System Quality -> E-Learning System Use & 1.464 & 0.144 & Rejected \\
\hline $\mathrm{H} 3$ & : System Quality -> Perceived Usefulness & 2.589 & 0.010 & Accepted \\
\hline $\mathrm{H} 4$ & : System Quality -> E-Learner Satisfaction & 1.612 & 0.108 & Rejected \\
\hline H5 & : Instructor Quality -> E-Learning System Use & 0.715 & 0.475 & Rejected \\
\hline H6 & : Instructor Quality -> Perceived Usefulness & 3.307 & 0.001 & Accepted \\
\hline H7 & : Instructor Quality -> E-Learner Satisfaction & 1.586 & 0.113 & Rejected \\
\hline H8 & : Learner Computer Anxiety -> E-Learner Satisfaction & 1.138 & 0.256 & Rejected \\
\hline H9 & : Perceived Usefulness -> E-Learning System Use & 5.717 & 0.000 & Accepted \\
\hline H10 & : Perceived Usefulness -> E-Learner Satisfaction & 2.708 & 0.007 & Accepted \\
\hline H11 & : Perceived Usefulness -> E-Learning System Success & 0.977 & 0.329 & Rejected \\
\hline H12 & $\begin{array}{l}\text { E-Learning System Use -> E-Learning System } \\
\text { Success }\end{array}$ & 1.572 & 0.117 & Rejected \\
\hline H13 & : E-Learner Satisfaction -> E-Learning System Success & 5.503 & 0.000 & Accepted \\
\hline
\end{tabular}

\section{Effect of Social Influence on System Use}

Social Influence (Social influence) or what is called subjective norm is the influence of individuals or groups that are considered important (for example, friends, family, spouse, co-workers, lecturers, etc.) as a reference for doing or not doing something (Ajzen, 2020). In this study, if students feel that people who are considered important (such as family, classmates, and lecturers) support the use of Google Classroom as a platform for online learning, then it is likely that students will be interested in using Google Classroom.

The structural model results in table 5 show that the $\mathrm{t}$-statistics of social influence on system use $(0.929)<1.96$, so H1 is rejected. This is contrary to the results of research by Jakkaew \& Hemrungrote (2017); Sukarya et al., (2021) which states that students think that they use e-learning because they are indirectly influenced by the opinions of people whom they consider important. 
However, this finding is also supported by the research of Dewi \& Zaky (2020) which states that the opinions of people around students (such as lecturers and classmates) about the use of e-learning systems do not affect students' perceptions of behavioral interest in using e-learning systems.

This means that students feel that people who are considered important (such as family, lecturers, and classmates) have not been able to encourage their behavior in using Google Classroom in the learning process. The people he considered important were only able to describe that using google classroom helped achieve academic achievement and was easy to use. The rest of, people who are considered important do not force student behavior to use google classroom, because it is the choice of each student not to or use google classroom.

\section{H1: Social influence has no significant effect on the use of the Google} classroom system

\section{Effect of System quality on System Use, Perceive usefulness, and User Satisfaction}

System quality is an assessment of the information system process in terms of the interaction between users and the system. Important elements in system quality such as the availability of tools, tool reliability, ease of use of tools, and speed of tool response time are determining factors why an information system is used or not used (Pawirosumarto, 2016). Teo (2011) states, technology acceptance is the interest of users to use technology in compiling user tasks. Furthermore, the TAM Model Theory states that the ease of the tool can affect the E-Learning System Use or LMS platform (Sunkara \& Kurra, 2017). Conceptually, the influence of system quality (in terms of availability of access, reliability of the tool, ease of use, and speed of response of the tool) can affect the use of the system.

Table 5 shows the t-statistic value of the influence of system quality on system use $(1.464)<1.96$, so $\mathrm{H} 2$ is rejected. This contradicts the results of Pawirosumarto (2016) which states that system quality can affect E-Learning System Use. The difference in these findings is because previous studies have different research objects. Pawirosumarto (2016) research has the object of having the object of a 
master's program student at Mercubuana University while the object in this study is an undergraduate student of PGMI Unisla.

This finding supported by the results of research by Aparicio et al., (2017); (Cidral et al., 2018); Al-Fraihat et al., (2020); Seliana et al. (2020) which states that system quality has no effect on E-Learning System Use. Therefore, it is concluded that system quality has no effect on the use of the google classroom system at PGMI Unisla. This shows that system quality (availability of tools, tool reliability, ease of use of tools, and speed) has not been able to affect the use of google classroom for PGMI Unisla students.

H2: System quality has no significant effect on the use of google classroom

The t-statistic value of the effect of system quality e-learning on perceived usefulness is above 1.96, which is 2.589 (see table 5), so H3 is accepted. Similar findings, on the effect of system quality e-learning on perceived usefulness, were found by Lwoga, (2014); Islam (2013) which states that system quality has a positive influence on perceived usefulness. So it can be concluded that the higher the Google Classroom system quality, the higher the perceived usefulness of Unisla PGMI students.

H3: System quality has a significant effect on Perceived usefulness

The t-statistic value of the influence of system quality on E-Learner Satisfaction $(1.612)<1.96$ (see table 5), so H4 is rejected, this is contrary to the results of Pawirosumarto, (2016); Jakkaew \& Hemrungrote, (2017); Khairrunnisa \& Yunanto (2017); Mtebe \& Raphael (2018) namely the higher the quality of the e-learning system (easy to use, and its practicality in completing the given task), the higher the level of E-Learner Satisfaction in the e-learning system. This is because previous studies have different research objects. Pawirosumarto, (2016) research, has the object of a master's program student at Mercubuana University while the object in this study is an undergraduate student of PGMI Unisla. Khairrunnisa \& Yunanto (2017) have the object of a Taxable Entrepreneur (PKP) while the object of this research is a student of PGMI Unisla. The research of Mtebe \& Raphael (2018) has the object of the Moodle e-learning platform while the object in this study uses the Google Classroom platform. 
The results of this study indicate that the google classroom quality system does not affect student satisfaction of PGMI Unisla. In other words, students feel satisfaction in using Google Classroom is not influenced by the availability of access, the reliability of Google Classroom, the ease with which Google Classroom is used, and the response speed of Google Classroom but is influenced by other factors.

H4: System quality has no significant effect on user satisfaction

\section{Influence of Instructor quality on System Use, Perceive usefulness and User Satisfaction}

Table 5 shows the t-statistic value of the influence of instructor quality on the use of the system is $1.586<1.96$, so H5 is rejected. The results of this study are consistent with the research conducted by Al-Fraihat et al. (2020); Zhao et al. (2019) yang menyebutkan bahwa tidak ada pengaruh signifikan antara kualitas instruktur terhadap penggunaan sistem. which states that there is no significant influence between instructor quality on the use of the system. This finding contradicts previous research which stated that there was a positive influence of instructor quality on the use of the system (Abbas, 2017).

H5: Instructor quality has no significant effect on the use of the system

Based on table 5, the t-statistic value of the influence of instructor quality on perceived usefulness is $3.307>1.96$, so H6 is accepted. This finding supports previous research which states that instructor quality has a significant effect on perceived usefulness by users (Islam, 2013). Because instructor quality affects perceived usefulness by PGMI Unisla students, universities need to improve instructor quality at PGMI Unisla so that instructors have theoretical and practical knowledge, prioritize students, and establish good interactions with students.

H6: Instructor quality has a significant effect on Perceived usefulness

The t-statistic value of the influence of instructor quality on E-Learner Satisfaction $(0.715)<1.96$ (see table 5), so H7 was rejected. This finding contradicts the previous research conducted by Islam (2013); Cidral et al. (2018); Zhao et al. 
(2019) with the findings that the higher the instructor quality, the higher the level of user satisfaction. This shows that instructor quality at PGMI has not been able to influence student satisfaction in using the google classroom learning system.

H7: Instructor quality has no significant effect on user satisfaction

\section{Effect of Learner computer anxiety on User Satisfaction}

In table 5, the results of the t-statistic value of the influence of learner computer anxiety on E-Learner Satisfaction $(1.138)<1.96$ are obtained, so H8 is rejected. The results of previous studies showed similar findings, namely learner computer anxiety did not affect user satisfaction. This finding shows that the satisfaction of PGMI Unisla students is not influenced by learner computer anxiety, this makes it possible that PGMI Unisla students are accustomed to interacting with digital technology during the covid 19 pandemics.

H8: Learner computer anxiety has a significant effect on user satisfaction

\section{Effect of Perceived usefulness on System Use and User Satisfaction}

Sunkara \& Kurra (2017) state that the TAM theory supports the effect of perceived usefulness of e-learning technology on the acceptance of e-learning systems by students to pursue online learning. According to Islam (2013), students' beliefs about the perceived usefulness of using e-learning can affect E-Learning System Use (such as reading, downloading lecture materials, conducting discussions, sending messages, and so on). The t-statistic value of the perceived usefulness effect on the use of the system in table 5 is $5.717>1.96$, so H9 is accepted. The results of this study are consistent with the findings of previous studies conducted by Al-Fraihat et al. (2020); Alsabawy et al. (2013); Lwoga (2014) which states that perceived usefulness by users has a significant effect on system use. However, this finding contradicts the research findings of Islam (2013) which shows that perceived usefulness does not affect system use. Based on the results of this study, which showed that there was a significant influence perceived usefulness of PGMI Unisla students on the use of the system, in this case, the Unisla PGMI study program needed to increase productivity, effectiveness, and control learning to influence students in using google classroom as a learning tool. 
H9: Perceive usefulness has a significant effect on the use of the system.

The t-statistic value of perceived usefulness effect on E-Learner Satisfactionlearning is 2.708> 1.96 (see table 5), so H10 is accepted, the results of this study support previous research conducted byAl-Fraihat et al. (2020); Islam (2013) which states that E-Learner Satisfaction is determined by the user's perceived usefulness.

H10: Perceive usefulness has a significant effect on E-Learner Satisfaction

\section{Effect of Perceived usefulness, E-Learning System Use and E-Learner Satisfaction on System Success}

Perceive usefulness and use of the system have no effect on E-Learning System Success with a significance value $(0.977<1.96) \mathrm{H} 11$ is rejected and $(1.572<1.96) \mathrm{H} 12$ is rejected. This shows that the perceived usefulness and use of the google classroom system for PGMI Unisla students have not been able to affect the success of the google classroom system.

H11: Perceive usefulness has no significant effect on system success

H12: The use of the system has no significant effect on the success of the system

However, the success of the Google Classroom system is influenced by user satisfaction. E-Learner Satisfaction is an important factor in determining the success of a system. The satisfaction measure includes satisfaction measures including adequacy, effectiveness, efficiency, pleasure, information satisfaction, overall satisfaction, and system satisfaction (Urbach \& Müller, 2012).

Based on the results of the research, the t-statistic value of the influence of E-Learner Satisfaction-learning on E-Learning System Success is significant $5.503>1.96$, so H13 is accepted. The results of this study consistently support Urbach \& Müller (2012) and Aparicio et al. (2017)

H13: E-Learner Satisfaction has a significant effect on system success

Based on the data above, it can be concluded that there are five accepted hypotheses, while the other eight hypotheses are rejected. The accepted 
hypotheses are $\mathrm{H3}, \mathrm{H} 6, \mathrm{H} 9, \mathrm{H} 10$, and $\mathrm{H} 13$, but $\mathrm{H} 1, \mathrm{H} 2, \mathrm{H} 4, \mathrm{H} 5, \mathrm{H} 7, \mathrm{H} 8, \mathrm{H} 11$, and H12 are rejected.

\section{CONCLUSION}

This study has important theoretical implications for the use of the Google classroom platform in online learning during the covid 19 pandemics. The results of this study indicate that social influence does not affect the use of google classroom, system quality does not affect system use and user satisfaction, but does affect perceived usefulness. Instructor quality has an effect on perceived usefulness, but has no effect on system use and user satisfaction. Learner computer anxiety does not affect user satisfaction. Finally, the success of the google classroom system is influenced by user satisfaction but is not influenced by system use and perceived usefulness. Furthermore, this research can be used as a consideration for the Unisla PGMI study program to plan and implement online learning using google classroom by paying attention to several aspects including, system quality, quality of instructors, perceived usefulness, and student satisfaction in using google classroom. This study has limitations, namely, the respondents only came from students of the Unisla PGMI study program. Therefore, the researcher suggests that future research can be carried out on all Google Classroom users at the Islamic University of Lamongan. In addition, this research model will better describe the success of using the system if several variables such as service/network quality and the quality of learning materials are added in influencing user satisfaction. 


\section{REFERENCES}

Abbas, T. (2017). Social factors affecting students' acceptance of e-learning environments in developing and developed countries A structural equation modeling approach. Journal of Hospitality and Tourism Technology, $34(1), 1-5$.

Ajzen, I. (2020). The theory of planned behavior: Frequently asked questions. Human Behavior and Emerging Technologies, 2(4), 314-324. https://doi. org/10.1002/hbe2.195

Al-Fraihat, D., Joy, M., Masa'deh, R., \& Sinclair, J. (2020). Evaluating E-learning systems success: An empirical study. Computers in Human Behavior, 102, 816. https:/ / doi.org/10.1016/j.chb.2019.08.004

Alsabawy, A. Y., Cater-Steel, A., \& Soar, J. (2013). IT infrastructure services as a requirement for e-learning system success. Computers and Education, 69, 431-451. https://doi.org/10.1016/j.compedu.2013.07.035

Aparicio, M., Bacao, F., \& Oliveira, T. (2017). Grit in the path to e-learning success. Computers in Human Behavior, 66, 396. https:/ / doi.org/10.1016/j. chb.2016.10.009

Cidral, W. A., Oliveira, T., Di Felice, M., \& Aparicio, M. (2018). E-learning success determinants: Brazilian empirical study. Computers and Education, 122(351), 273-290. https:/ / doi.org/10.1016/j.compedu.2017.12.001.This

Dewi, I. K., \& Zaky, A. (2020). Faktor-Faktor yang Mempengaruhi Penggunaan E- Learning Systems dalam Proses Belajar Mahasiswa Universitas Brawijaya. Jurnal Ilmiah Mahasiswa FEB Universitas Brawijaya, 7(2), 27.

Direktorat Jenderal Pendidikan Tinggi Kemdikbud RI. (2020). Buku Panduan Penyelenggaraan Pembelajaran Semester Gasal 2020/2021 di Perguruan Tinggi.

Furadantin, N. R. (2018). Structural Equation Modeling- Partial Least Square (SEM PLS). Academia.edu. https://www.academia.edu/38055252/Analisis_ Data_Menggunakan_Aplikasi_SmartPLS_v_3_2_7_2018

Hair, J. F., Sarstedt, M., Hopkins, L., \& Kuppelwieser, V. G. (2014). Partial least squares structural equation modeling (PLS-SEM): An emerging tool in business research. European Business Review, 26(2), 111. https://doi. org/10.1108/EBR-10-2013-0128 
Harefa, N., \& Sumiyati, S. (2020). Persepsi Siswa terhadap Google Classroom sebagai LMS pada masa Pandemi Covid-19. Science Education and Application Journal, 2(2), 88. https:/ / doi.org/10.30736/seaj.v2i2.270

Islam, A. K. M. N. (2013). Investigating e-learning System Usage Outcomes in the University Context. Computers and Education, 69, 387-399. https://doi. org/10.1016/j.compedu.2013.07.037

Jakkaew, P., \& Hemrungrote, S. (2017). The use of UTAUT2 model for understanding student perceptions using Google Classroom: A case study of Introduction to Information Technology course. 2nd Joint International Conference on Digital Arts, Media and Technology 2017: Digital Economy for Sustainable Growth, ICDAMT 2017, 205-209. https://doi.org/10.1109/ ICDAMT.2017.7904962

Kamil, I. (2020). Survei: Google Classroom Jadi Platform Belajar Paling Sering Digunakan Saat PJJ. Kompas.com. https://amp.kompas.com/nasional/ $\mathrm{read} / 2020 / 10 / 16 / 18264341 /$ survei-google-classroom-jadi-platformbelajar-paling-sering-digunakan-saat

Khairrunnisa, U., \& Yunanto, M. (2017). Pengaruh Kualitas Sistem Terhadap Kepuasan Pengguna Dan Manfaat Bersih Pada Implementasi E-Faktur: Validasi Model Kesuksesan Sistem Informasi Delone Dan Mclean. Jurnal Ilmiah Ekonomi Bisnis, 22(3), 229011. https:// doi.org/10.35760/eb.

Lwoga, E. (2014). Critical success factors for adoption of web-based learning management systems in Tanzania. International Journal of Education and Development using Information and Communication Technology (IJEDICT), 10(1), 4-21. http:/ /ijedict.dec.uwi.edu/viewarticle.php?id=1669

Mishra, L., Gupta, T., \& Shree, A. (2020). Online teaching-learning in higher education during lockdown period of COVID-19 pandemic. International Journal of Educational Research Open, 1(September), 100012. https://doi. org/10.1016/j.ijedro.2020.100012

Mtebe, J. S., \& Raphael, C. (2018). Key factors in learners' satisfaction with the e-learning system at the University of Dar es Salaam, Tanzania. Australasian Journal of Educational Technology, 34(4), 107-122. https:/ / doi. org/10.1111/j.1747-1567.2009.00538.x

Ouajdouni, A., Chafik, K., \& Boubker, O. (2021). Measuring e-learning systems success: Data from students of Higher Education Institutions in Morocco. Data in Brief, 106807. https:/ / doi.org/10.1016/j.dib.2021.106807 
Pawirosumarto, S. (2016). Pengaruh Kualitas Sistem, Kualitas Informasi, dan Kualitas Layanan terhadap Kepuasan Pengguna Sistem e-Learning. MIX: Jurnal Ilmiah Manajemen, 6(3), 333-348.

Rahmat, A., Seminar, K. B., \& Suroso, A. I. (2019). Evaluasi Keberhasilan E-Learning Dalam Perspektif Sistem Informasi (Studi Kasus Universitas Terbuka). Jurnal Aplikasi Bisnis dan Manajemen, 5(3), 373-384. https:/ / doi. org/10.17358/jabm.5.3.373

Ramadhani, R., Umam, R., Abdurrahman, A., \& Syazali, M. (2019). The effect of flipped-problem based learning model integrated with LMS-google classroom for senior high school students. Journal for the Education of Gifted Young Scientists, 7(2), 137-158. https:/ / doi.org/10.17478/jegys.548350

Ramadhani, S., \& Gustin, E. (2020). Tanggapan Mahasiswa terhadap Pemanfaatan Google Classroom sebagai Media Pembelajaran Online. JUSTIN (Jurnal Sistem dan Teknologi Informasi), 8(3), 278-281. https://doi.org/10.26418/ justin.v8i3.40007

Sarstedt, M., Ringle, C. M., \& Hair, J. F. (2017). Partial Least Squares Structural Equation Modeling. In Handbook of Market Research (Nomor September). Springer International Publishing AG. https://doi.org/10.1007/978-3319-05542-8

Seliana, N., Suroso, A. I., \& Yuliati, L. N. (2020). Analisis Keberhasilan Penerapan E-Learning di Fakultas Teknik Universitas Riau. Jurnal Aplikasi Bisnis dan Manajemen, 6(2), 369-378. https://doi.org/10.17358/jabm.6.2.369

Shaharanee, I. N. M., Jamil, J. M., \& Rodzi, A. S. S. M. (2016). The application of Google Classroom as a tool for teaching and learning. Journal of Telecommunication, Electronic and Computer Engineering, 8(10), 5-8.

Sukarya, I. G. A., Pradnyana, I. M. A., \& Sugihartini, N. (2021). Analisis FaktorFaktor Yang Mempengaruhi Perilaku Penggunaan Sistem E-Learning Undiksha Dengan Model Unified Theory of Acceptance and Use of Technology (UTAUT). INSERT: Information System and Emerging Technology Journal, 1(2), 1. https:/ / doi.org/10.23887/insert.v1i2.25940

Sunkara, V. M., \& Kurra, R. R. (2017). An Analysis of Learner Satisfaction and Needs on E-Learning Systems. International Journal of Computational Intelligence Research, 13(3), 434. http:/ / www.ripublication.com 
Talebian, S., Mohammadi, H. M., \& Rezvanfar, A. (2014). Information and Communication Technology (ICT) in Higher Education: Advantages, Disadvantages, Conveniences, and Limitations of Applying E-learning to Agricultural Students in Iran. Procedia - Social and Behavioral Sciences, 152, 300-305. https://doi.org/10.1016/j.sbspro.2014.09.199

Teo, T. (2011). Technology Acceptance Research in Education. In Technology Acceptance in Education (hal. 1). https://doi.org/10.1007/978-94-6091487-4

Urbach, N., \& Müller, B. (2012). The Updated DeLone and McLean Model of Information Systems Success. In Information Systems Theory: Explaining and Predicting Our Digital Society (Vol. 1, hal. 1-18). Springer. https:/ / doi. org/10.1007/978-1-4419-6108-2

Wong, K. K. K.-K. (2013). Partial Least Squares Structural Equation Modeling (PLS-SEM) Techniques Using SmartPLS. Marketing Bulletin, 24(1), 21. http://marketing-bulletin.massey.ac.nz/v24/mb_v24_t1_wong. pdf\%5Cnhttp://www.researchgate.net/profile/Ken_Wong10/ publication/268449353_Partial_Least_Squares_Structural_ Equation_Modeling_(PLS-SEM)_Techniques_Using_SmartPLS/ links/54773b1b0cf293e2da25e3f3.pdf 